\title{
APPLICATION OF X-RAY MICROANALYSIS TO THE STUDY OF CELL PHYSIOLOGY IN CELLS ATTACHED TO BIOMATERIALS
}

\author{
Godfried M. Roomans \\ Department of Medical Cell Biology, University of Uppsala, Sweden
}

\begin{abstract}
X-ray microanalysis is commonly applied in biomaterials research to study changes in biomaterial composition, calcifications, or to identify particulates in tissue that has been in contact with biomaterials. Studies where the effect of biomaterials on the naturally occurring elements in the cells are studied are rare. Exposure to or contact with biomaterials may give rise to several cellular reactions with characteristic changes in elemental patterns. Experimental systems in which cultured cells are exposed to biomaterials, and the resulting changes in elemental content measured by X-ray microanalysis are presented. Proliferation results in an increase in $\mathrm{Mg}, \mathrm{P}$ and $\mathrm{K}$. Injury and necrosis result in increased $\mathrm{Na}, \mathrm{Cl}$ and $\mathrm{Ca}$, and decreased $\mathrm{K}$ and $\mathrm{Mg}$. The $\mathrm{Na} / \mathrm{K}$ ratio is a sensitive indicator of cell damage. Apoptosis results in increased $\mathrm{Na} / \mathrm{K}$ and an increase $\mathrm{P} / \mathrm{S}$ ratios. Mechanical effects of biomaterials may cause changes in cellshape or cell volume that may result in volume-regulating ion fluxes, e.g., of chloride, accompanies by efflux of potassium. The multi-element detection capability of X-ray microanalysis makes it particularly suitable to detect these characteristic patterns of changes. The technique can also be used to define subpopulations of cells that differ with respect to their reactions to external stimuli.
\end{abstract}

Key Words: X-ray microanalysis, biomaterials, proliferation, necrosis, apoptosis, ion transport, cell cultures.

Address for correspondence:

Department of Medical Cell Biology,

University of Uppsala,

Box 571,

SE-75123 Uppsala,

Sweden

Telephone number: $+46-18-4714114$

Fax number: +46-18-551120

E-mail: godfried.roomans@medcellbiol.uu.se

\section{Introduction}

X-ray microanalysis is routinely applied in biomaterials research to study e.g., elemental changes in the biomaterial, or calcifications induced in the tissue by the presence of biomaterials, or to identify the chemical nature of particulates present in tissue that has been in contact with a biomaterial. Very few studies have been carried out investigating the effect of biomaterials on the elemental composition of cells exposed to biomaterials (Nkamgueu et al., 2000). Biomaterials can induce a variety of effects on cells that are regularly checked for: necrosis, apoptosis and cell proliferation (or inhibition of cell proliferation) (e.g., Prabhu et al., 1998; Fabre et al., 1999; Cimpan et al., 2000; Brodbeck et al., 2001; Pariente et al., 2001). Cells in contact with biomaterials can be subjected to mechanical stress leading to shape and volume changes and this in its turn can result in ion fluxes that change the elemental composition of the cell (Sarkadi and Parker, 1991; Tobasnick and Curtis, 2001). The aim of the present paper is to introduce the biomaterials community to the potential that X-ray microanalysis has to provide information on the physiological state of cells in contact with biomaterials. It will be argued that X-ray microanalysis could be used to detect patterns of elemental changes that are typical for proliferation, apoptosis, necrosis, or ion fluxes related to volume changes, and that therefore the use of this technique in biomaterials research should be considered more frequently.

\section{Energy-dispersive X-ray microanalysis}

Electron probe X-ray microanalysis is a technique of elemental analysis that is based on the generation of characteristic X-rays in atoms of the specimen by the incident beam electrons (reviewed by Roomans 1988a, 1990; Warley, 1997). These X-rays are characteristic for the element from which they originate, and hence contain information on which elements are present in the specimen. Xray microanalysis of biological specimens is commonly carried out with a semiconductor detector that collects Xrays of all energies simultaneously. This technique is called energy-dispersive analysis, to distinguish it from an older detection technique called wavelength-dispersive analysis. The latter method is based on filtering out one particular wavelength (element) from the X-ray spectrum in a crystal spectrometer. Wavelength-dispersive X-ray microanalysis detects one element at a time.

In principle, the number of X-rays for a specific element generated by the electron beam is linearly related to 


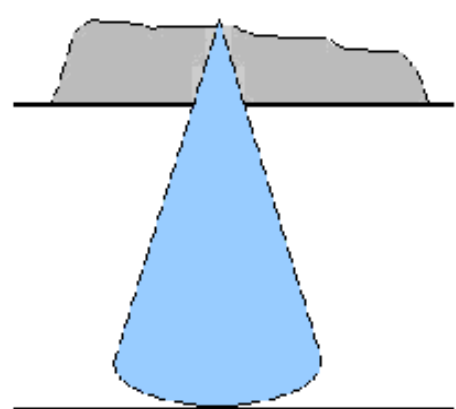

$\mathbf{a}$

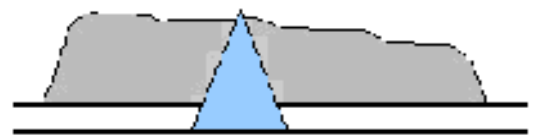

b

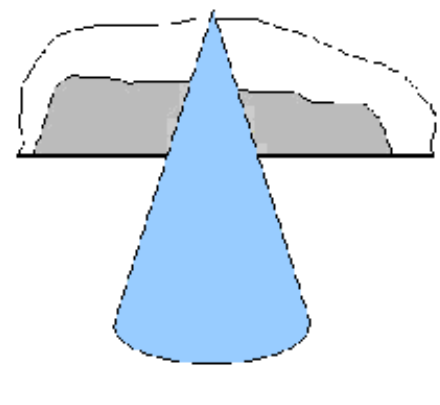

c

Figure 1. Schematic drawings representing the conditions of analysis of cultured cells. Grey: cultured cell. Blue: volume excited by the electron beam. (a) Cells cultured on a solid substrate. The electron beam penetrates the cell completely and excites the substrate. Therefore, a considerable part of the spectrum comes from the substrate. Depending on the type of substrate and the type of detector, a peak for the substrate may be observed in the spectrum, e.g., if one would have a glass substrate, a Si peak would be observed. If one would have a carbon substrate, and carry out the analysis with a conventional detector with beryllium window, one would not see a $\mathrm{C}$ peak, but the substrate would contribute to the background intensity, making fully quantitative analysis using only peak/continuum ratios impossible. (b) Cells cultured on an electron microscope grid. Only a thin plastic film is present below the cells. The spectrum contains a contribution from the grid (both characteristic X-rays if the grid is made of metal, and continuum X-rays). Methods to correct for this contribution are available. (c) If the cells are washed with a non-volatile washing fluid, such as mannitol, the cells will after freeze-drying be covered with a mannitol layer that "dilutes" the signal from the cell. With regard to quantitative analysis, this situation is similar to the one described in (a), and fully quantitative analysis using only peak/continuum ratios is impossible. If the experimental medium is not removed by washing, this layer will, in addition contain high concentrations of $\mathrm{Na}$ and $\mathrm{Cl}$ that contribute to the spectrum. In this case, also qualitative analysis will be flawed.

the number of atoms of that element in the analyzed volume. In addition to characteristic X-rays, the beam electrons generate background or continuum X-rays. These continuum X-rays are generated when the incident electrons are decelerated in the electromagnetic field of the nucleus of atoms in the specimen. The continuum X-rays do not carry information about the elemental composition of the sample. However, the intensity of the background radiation is related to the total mass of the analyzed volume. Hence the ratio of the characteristic X-ray radiation and the background radiation is related to the concentration of the element in the analyzed volume. The lowest concentration of an element that can be detected is in the order of a few $\mathrm{mmol} / \mathrm{kg}$. The spatial resolution of the analysis depends on the thickness of the specimen. The best spatial resolution is obtained in (thin) specimens where as a rule of thumb the diameter of the analyzed volume is about half the section thickness. If bulk specimens are analyzed, as is done in the scanning electron microscope, the spatial resolution depends on the accelerating voltage and the composition of the specimen. A typical value for analysis of freeze-dried biological material at an accelerating voltage of $20 \mathrm{kV}$ is about $10 \mu \mathrm{m}$.

$\mathrm{X}$-ray microanalysis of cultured cells can be a useful technique to investigate the effect of extraneous compounds (toxic or irritating substances, biomaterials) on the elemental composition of the cell. The advantages of the use of cell cultures in general are well-known: the cell culture system is simpler since it usually consists of only one cell type, systemic effects can be avoided, and especially in the case of human cells in vivo experiments are often not possible because of practical or ethical constrictions. Preparation of cell cultures for X-ray microanalysis is often simpler than preparation of tissue, because dissection artefacts can be avoided. The main advantage of X-ray microanalysis over other techniques used for investigating ion transport (e.g., radioactive tracers, fluorescent probes) is that with energy-dispersive X-ray microanalysis all elements of interest can be measured simultaneously.

\section{Preparation of cultured cells for X-ray microanalysis}

It should be borne in mind that conventional fixation techniques for electron microscopy cause major changes in the elemental content of the cells. Aldehyde fixation causes leakage of all diffusible ions from the cell. Hence, non-aqueous low-temperature specimen preparation techniques are generally used if the analysis of naturally occurring diffusible ions is of interest. The two systems that have been used most frequently for cultured cells are: (a) to grow the cells on a solid substrate, or (b) to grow the cells on a very thin substrate, e.g., a thin plastic film on an electron microscopy grid (von Euler et al. 1993; Roomans, 2002)

X-ray microanalysis of cells cultured on a solid substrate is a technically easy method. The specimens are sturdy, easy to handle, and easy to analyze. The disadvantage of this system is that it is often impossible to avoid overpenetration of the specimen by the electron beam (Fig. 1a). This means that the X-ray spectrum obtained is not only due to the specimen but also to the substrate. The consequences of this will be discussed below. In general only the thickest part of the cell can be analyzed, no analy- 

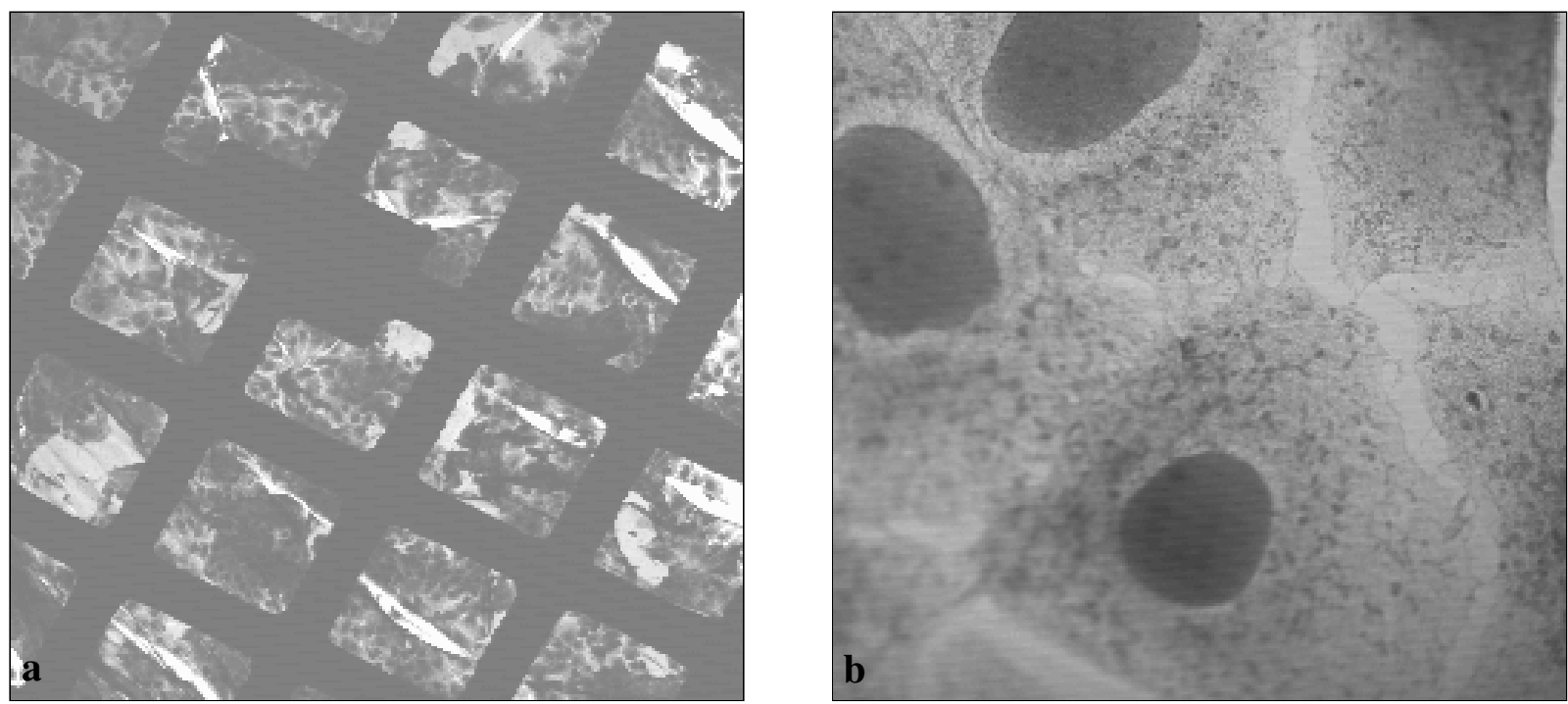

Figure 2. Scanning transmission electron micrographs of keratinocytes (HaCaT cells) cultured on thin films on titanium grids (Grängsjö et al., 2000a). (a) Low magnification overview, showing grid bars, (b) Higher magnification, showing that the nucleus can be distinguished from the cytoplasm.

sis at the subcellular level is possible. Sensitivity of analysis at low accelerating voltage is lower than at high accelerating voltage. Analysis requires a scanning electron microscope. This technique could be used for analysis of cells growing directly on a biomaterial.

$\mathrm{X}$-ray microanalysis of cells cultured on thin films on grids in the STEM is more sensitive and quantitative analysis can be more straightforward (Fig. 1b, Fig. 2a,b). It may be possible to analyze areas with cytoplasm only and compare these with the area containing both nucleus and cytoplasm. The specimens are, however, more fragile, and when the film breaks during handling of the grid, the grid cannot be analyzed and part of an experiment may be spoiled. Analysis requires a (scanning) transmission electron microscope. The contribution of the titanium or gold grid to the spectrum may be a problem, especially in quantitative analysis. This technique could be used for analyzing the effect of soluble substances (e.g., biomaterials extracts) on the cultured cells.

In both methods, the cells are grown on the substrate using appropriate cell culture methods. Before the cells can be frozen, the culture medium or the experimental solution has to be removed. In general, these solutions will contain physiological concentrations of $\mathrm{Na}^{+}$and $\mathrm{Cl}^{-}$ions. If the cells are frozen and freeze-dried without removing these solutions, the ions would come to cover the cells and an artificially high $\mathrm{Na}$ and $\mathrm{Cl}$ concentration would be observed in the measurement. Therefore, before freezing, the cells should be washed with a solution that does not contain any elements that could disturb the analysis.

Three different types of fluids can be used for the rinsing step: (a) distilled water, (b) volatile buffers, e.g., ammonium acetate, or (c) isotonic sugar solutions (Abraham et al., 1985; Zhang and Roomans, 1998; Dragomir et al., 2001). Distilled water has the advantage that it does not leave any remnants after freeze-drying. It may, however, cause osmotic shock, and induce efflux of ions either by general damage to the membrane or by specific ion transport mechanisms. Ammonium acetate is volatile, and most or all of this compound will disappear after freeze-drying, leaving little or no remnants. Though a $150 \mathrm{mM}$ ammonium acetate solution is about isoosmotic with the cytoplasm, ammonium acetate may cause $\mathrm{pH}$ changes in the cell and thereby induce ion transport. A $300 \mathrm{mM}$ mannitol solution is iso-osmotic and is not expected to cause changes in the ionic content of the cells. However, after freeze-drying the cells are covered with a thin layer of powdery mannitol (Fig. 1c). Some of this may be removed by careful brushing, but some will remain. This makes visualization of the cells more difficult and also adds a layer of organic substance to the specimen that "dilutes" the signal from the cell. This can be a problem in quantitative analysis. In our experience, some cell types withstand washing with ice-cold distilled water or ammonium acetate and in such a case these solutions are to be preferred. If the cells obviously lose ions after washing with water or ammonium acetate, then mannitol or a substance with similar properties should be used. (We find sucrose, however, to be even more sticky than mannitol). The best way to make sure that the rinsing procedure does not introduce artifacts is to compare whole-mount specimens, rinsed in different washing fluids, with cryosections of the same cells, frozen without rinsing (Warley et al., 1994; Dragomir et al., 2001). The procedure to use cryosections of cultured cells avoids the problems of the "whole mounts" (Zierold et al., 1994) but is a cumbersome procedure not suitable if data from more than a very small number of cells have to be collected.

\section{Quantitative analysis}

As stated above, the ratio of characteristic to continuum radiation ("peak-to-background ratio") is linearly related to the concentration of the element investigated, and only needs to be compared with a standard or standard curve to 
Table 1. Effects of damage on elemental concentrations as measured by X-ray microanalysis.

\begin{abstract}
system
nerve cell axons

small intestine, in situ enterocytes

small intestine, in situ, goblet cells

cultured enterocytes

cultured bronchial epithelial cells

cultured bronchial epithelial cells
\end{abstract}

$\begin{array}{lllllll}\text { type of damage } & \text { Na } & \mathbf{M g} & \mathbf{C l} & \mathbf{K} & \mathbf{C a} & \\ \text { axotomy } & 121 & 95 & 100 & 70 & 140 & \\ \text { radiation } & 380 & 33 & 161 & 86 & 100 & \\ \text { radiation } & 133 & 100 & 123 & 74 & 200 & \\ \text { radiation } & 325 & 67 & 109 & 59 & 100 & \\ \text { TNF- } \alpha & & 189 & 105 & 155 & 100 & \text { nd } \\ \text { hypochlorite } & 150 & 92 & 157 & 92 & \text { nd } & \end{array}$

Data expressed in $\%$ of control. TNF- $\alpha=$ tumor necrosis factor a. nd = not determined (below detectable level). Data from Wróblewski et al. (2000, 2002), Kampf et al. (1999) and Kampf and Roomans (2001).

generate fully quantitative data. Quantitative techniques for biological specimens have been described in the literature (e.g., Roomans 1988b, 1990; Warley, 1997) and are provided with at least some of the commercially available systems. The following possible complications should be kept in mind:

(a) The continuum intensity is not just dependent on the mass of the analyzed volume, but also on its elemental composition, because heavy elements produce more continuum intensity than light elements. A correction factor, consisting of the weighted mean of $\mathrm{Z}^{2} / \mathrm{A}$ (where $\mathrm{Z}$ is the atomic number and $A$ the atomic weight) of all elements present in the analyzed volume is used to correct for this effect. The correction is available with standard software for quantitative biological X-ray microanalysis. If only "physiological" elements are present in the cell (up to $\mathrm{Ca}$ with $Z=20$ ), the correction is of very little significance, and could be neglected. If, however, the cell has taken up heavy elements, the correction may become important.

(b) When cells grown on a thin film on a grid are analyzed, a peak for the grid metal is seen, despite the fact that the beam is placed on the cell. This is mainly due to a small proportion of beam electrons that, when they hit the cell, are scattered over a large angle, and then hit the grid bars. Similarly, such electrons may hit the specimen holder. Apart from generating characteristic X-rays from the grid and/or specimen holder, these electrons also generate continuum radiation that does not come from the specimen but from the grid/specimen holder (the mechanism for generation of continuum X-rays is described above). The observed continuum intensity therefore has to be corrected for the contribution that grid and/or specimen holder make to the continuum intensity, the "extraneous" continuum. Otherwise, the continuum intensity would be overestimated, and the resulting peak/continuum ratios would be too low. Methods for correction for extraneous background have been published and are available in the software. The theoretical model for this correction is, however, simplified and the correction will introduce some uncertainty if the extraneous background is large, e.g., if the measurement is carried out near a grid bar.

(c) When cells grown of a solid substrate are analyzed, the substrate will contribute to the spectrum if the beam completely penetrates the specimen (Fig. 1a). This is generally the case when cell monolayers are analyzed (freeze- dried biological samples have a rather low density). Penetration can be decreased by decreasing the accelerating voltage, but this results in a decrease of the signal. In practice, therefore, one often has to accept that the substrate is excited by the electron beam. The substrate should hence never contain an element of interest (which makes glass totally unsuitable as a substrate). With regard to quantitative analysis, the substrate "dilutes" the cell, and fully quantitative data cannot be obtained.

A general solution when there are problems with the determination of the continuum intensity is to carry out a determination of ratios between elements. (This is sometimes referred to as "semi-quantitative analysis"). These elemental ratios can be determined from the ratio of the characteristic intensities for two elements, and since the continuum intensity does not enter into the calculation, problems in determining the continuum intensity (or extraneous contributions to the continuum intensity) do not play a role. Information on changes in the concentration ratios of two elements, e.g., the $\mathrm{Na} / \mathrm{K}$ ratio, can well have biological significance comparable to the absolute concentrations of these elements. In short-term experiments (minutes) it can be assumed that the cellular concentration of phosphorus and sulfur is not affected, and these concentrations can be used as "internal standards". This is, however, not necessarily the case in longer-term experiments.

$\mathrm{X}$-rays that are generated in the specimen may be absorbed before they can emerge from the surface. Low-energy X-rays are more prone to absorption than high-energy X-rays, and so the extent of X-ray absorption is different for different elements. If the specimen consists of freeze-dried cells or soft tissue, and is no more than some $\mathrm{mm}$ thick, the correction for absorption is negligible. When the specimen is thicker, and fully quantitative analysis is carried out, a correction for absorption 'can be "automatically" applied by determining the continuum intensity in the same energy range as the characteristic intensity. This "background under the peak" is absorbed to (about) the same extent as the characteristic intensity, and in the ratio, the absorption correction is cancelled out. In practice, most cases of analysis of biological specimens should be covered by either of these two situations, and a separate correction for absorption need not to be applied.

For quantitative analysis of (bio)materials routines are given in the commercially available software. 
Table 2. Changes in elemental content related to proliferation.

$\begin{array}{llllll}\text { proliferative condition } & \text { Na } & \text { Mg } & \text { P } & \text { Cl } & \text { K } \\ \text { psoriasis (skin) } & 64 & 175 & 168 & 71 & 192 \\ \text { basalioma (skin) } & 88 & 142 & 132 & 100 & 164\end{array}$

Data expressed in \% of non-affected cells in the same tissue. Data from Grängsjö et al. (unpublished) and Wallberg et al. (2000).

\section{Elemental changes associated with cellular processes}

\section{Necrosis and cell damage}

Necrosis, or cell death, is associated with profound changes in membrane permeability. Since ATP is no longer produced, ATP-dependent membrane pumps stop working and ions will move entirely according to their concentration gradients. This will result in an increase in cellular $\mathrm{Na}, \mathrm{Cl}$ and $\mathrm{Ca}$, since these elements are present in a higher concentration in the extracellular medium. In contrast, the intracellular concentration of $\mathrm{K}$ and $\mathrm{Mg}$ will decrease (Table 1). Examples of this are post-mortem changes in elemental content (Kuijpers and Roomans, 1980), various types of injury such as chemical, mechanical or radiation injury (e.g., Grängsjö et al., 1996; Wróblewski et al., 2000, 2002), or changes due to anoxia, such as happens when tissue is removed from an experimental animal (Hongpaisan et al., 1996). Exposure of cultured cells to toxic or noxious substances will result in a similar pattern of elemental changes (Kampf et al., 1999; Grängsjö et al., 2000a; Kampf and Roomans, 2001). Also transient cell damage will give rise to changes with this pattern, although it is well possible that the changes are reversed when the cells recover (Hongpaisan et al., 1996). If elemental ratios are used instead of absolute concentrations, the $\mathrm{Na} / \mathrm{K}$ ratio (or the $\mathrm{K}$ / $\mathrm{Na}$ ratio) is a sensitive indicator for cell damage. The concentration of $\mathrm{P}$ remains the same as in the undamaged cell or decreases somewhat if structural damage is extensive. The concentration of S generally remains unchanged.

\section{Proliferation}

An increase in the rate of cellular proliferation results in an increase in the cellular concentration of $\mathrm{P}, \mathrm{Mg}$ and $\mathrm{K}$, whereas the concentrations of $\mathrm{Na}, \mathrm{S}$ and $\mathrm{Cl}$ are not much affected (Table 2). The cellular concentration of P mainly reflects the phosphate groups of the nucleic acids (DNA and RNA). The preferred cations for these phosphate groups are $\mathrm{K}^{+}$and $\mathrm{Mg}^{2+}$, so it is to be expected that these elements follow the changes in $\mathrm{P}$. Co-variance in $\mathrm{Mg}, \mathrm{P}$ and $\mathrm{K}$ concentrations is frequently observed (Grängsjö et al., 2000a). If elemental ratios are used instead of absolute concentrations, the $\mathrm{K} / \mathrm{Na}$ ratio (or the $\mathrm{Na} / \mathrm{K}$ ratio) is a sensitive indicator. Examples of cell proliferation can be found in psoriasis (Grundin et al., 1985; Grängsjö et al., unpublished data), where keratinocytes in the affected areas of the skin were found to have higher concentrations of $\mathrm{Mg}$, $\mathrm{P}$ and $\mathrm{K}$ than keratinocytes in unaffected areas, and in basalioma, where tumor cells were shown to have higher concentrations of $\mathrm{Mg}, \mathrm{P}$ and $\mathrm{K}$ than control keratinocytes (Wallberg et al., 2000). In an experiment where keratinocytes were exposed to the irritant substances so- dium dodecyl sulfate or nonanoic acid (Grängsjö et al., $2000 \mathrm{~b}$ ), changes in the $\mathrm{Na} / \mathrm{K}$ paralleled changes in the proliferative activity of the cells as determined by the Ki67 antibody. In the initial stage of the exposure, cell damage occurred, as seen from the increase in the $\mathrm{Na} / \mathrm{K}$ ratio. After $24 \mathrm{~h}$, the cells started to proliferate, as seen from the increase in $\mathrm{Ki} 67$, and this was accompanied by a decrease in the $\mathrm{Na} / \mathrm{K}$ ratio (increase in $\mathrm{K} / \mathrm{Na}$ ) (Fig. 3).

\section{Apoptosis}

Apoptosis is associated with a higher $\mathrm{Na} / \mathrm{K}$ ratio and an increased concentration of $\mathrm{P}$. The higher $\mathrm{Na} / \mathrm{K}$ ratio may in part be related to damage to the cell membrane and/or a decrease in metabolic rate of the cell, but also to specific activation of $\mathrm{K}^{+}$channels. Only a few studies on elemental changes in apoptosis have so far been carried out. Fernández-Segura et al. (1999) showed in UV-induced apoptosis in U937 cells a significant decrease in $\mathrm{Cl}$ and $\mathrm{K}$ content, and a significant increase in $\mathrm{Na}$. In addition, a tendency to higher $\mathrm{P}$ and $\mathrm{Ca}$ was noted. An increase in the cellular $\mathrm{Na} / \mathrm{K}$ ratio was also found in monocytemacrophages undergoing apoptosis (Skepper et al., 1999). Given the paucity of studies in this area, more work is needed before we fully understand the reasons behind the observed changes.

Etoposide is a drug that induces apoptosis in prostate

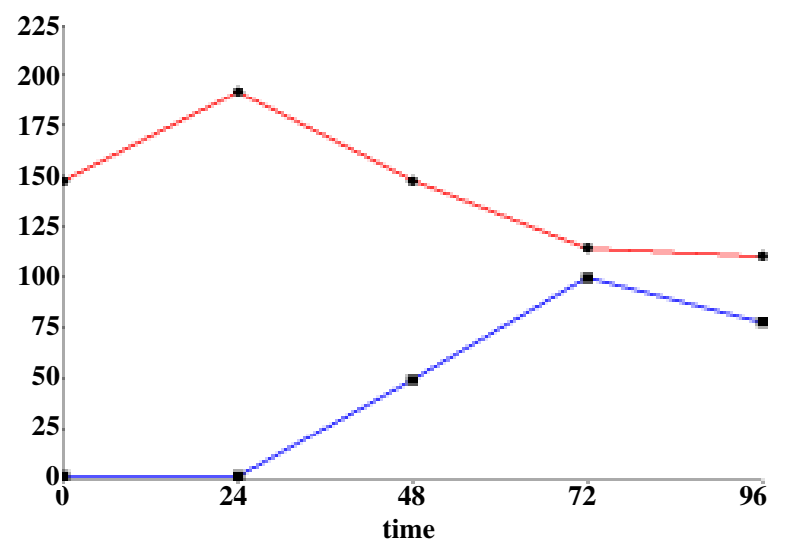

Figure 3. Effect of 4\% sodium lauryl sulfate (SLS) on keratinocytes in human skin in situ. Blue line: determination of proliferation with the Ki67 antibody. Red line: changes in the $\mathrm{Na} / \mathrm{K}$ ratio determined by X-ray microanalysis. During the first $24 \mathrm{~h}$ after application of SLS, cell damage occurs, resulting in an increased $\mathrm{Na} / \mathrm{K}$ ratio. When the cells start to proliferate as shown by the Ki67 antibody, the $\mathrm{Na} / \mathrm{K}$ ratio decreases again (increased $\mathrm{K} / \mathrm{Na}$ ratio). Data from Grängsjö et al. (2000b). 
Table 3. Changes in elemental content related to apoptosis

$\begin{array}{lllllllll}\text { Cells } & \text { Na } & \text { Mg } & \text { P } & \text { S } & \text { Cl } & \text { K } & \text { Na/K P/S } \\ \text { DU145 prostate cancer cells } & 357 & 130 & 148 & 78 & 105 & 65 & 560 & 191 \\ \text { PC3 prostate cancer cells } & 140 & 133 & 116 & 68 & 85 & 100 & 140 & 170\end{array}$

Data expressed in \% of control cells, apoptosis was induced by treatment with etoposide (Salido et al., 2002 and unpublished data).

Table 4. Changes in elemental content related to volume-regulating ion fluxes

$\begin{array}{llll}\text { experimental condition } & \text { Na } & \text { Cl } & \text { K } \\ \text { hypo-osmotic conditions } & 36 & 42 & 80 \\ \text { hypo-osmotic conditions + chloride channel blocker } & 96 & 97 & 100 \\ \text { hypo-osmotic conditions + calcium chelator } & 93 & 100 & 104\end{array}$

Data expressed in \% of control (iso-osmotic conditions). Data from Zhang and Roomans (1998).

cancer cells. Salido et al. (2001, 2002) observed that etoposide treatment consistently induced an increase in the cellular $\mathrm{Na}$ concentration and a decrease in the cellular $\mathrm{K}$ concentration, resulting in a marked increase of the $\mathrm{Na} / \mathrm{K}$ ratio. In addition, the $\mathrm{P} / \mathrm{S}$ ratio increased as a result of etoposide exposure, due to an increase in $\mathrm{P}$ and a concurrent decrease in $\mathrm{S}$ (Table 3). Changes in $\mathrm{Mg}$ appear to parallel those in P. Both bombesin and calcitonin inhibit the etoposide-induced changes in the cellular $\mathrm{Na} / \mathrm{K}$ ratio, and calcitonin, but not bombesin, inhibits in addition the changes in $\mathrm{P} / \mathrm{S}$ ratio. The changes in $\mathrm{P} / \mathrm{S}$ ratio may be related to a change in the ratio of nucleus to cytoplasm, since the $\mathrm{P}$ concentration is mainly dependent on the cellular nucleic acid concentration and $\mathrm{S}$ is mainly an indicator of the cellular protein content. However, in a recent study on an androgen-dependent prostate cancer cell line, we again observed an increase in $\mathrm{P}$, but now also an increase in $\mathrm{S}$ was noted, resulting in a decreased $\mathrm{P} / \mathrm{S}$ ratio (Salido et al., unpublished results). As with the androgen-independent cell lines, an increased $\mathrm{Na} / \mathrm{K}$ ratio was observed. Again, bombesin and calcitonin were effective in inhibiting the changes in elemental content induced by etoposide. However, neither bombesin nor calcitonin caused in themselves consistent significant changes in the elemental content of the cells. These data point to a strong link between elemental changes and apoptosis.

\section{Volume-regulating ion fluxes}

Zhang and Roomans (1998) demonstrated volumeregulating chloride efflux in cultured intestinal epithelial cells (HT29 cells) as a decrease of the $\mathrm{Cl}$ content of the cells. The efflux was induced by exposing the cells to a hypo-osmotic medium. In parallel, the $\mathrm{K}$ content of the cell decreased (Table 4). This is due to the fact that to maintain electroneutrality, $\mathrm{Cl}^{-}$efflux across the apical cell membrane is accompanied by $\mathrm{K}^{+}$efflux across the basolateral cell membrane. The fact that $\mathrm{Cl}^{-}$efflux is accompanied by $\mathrm{K}^{+}$efflux has been demonstrated by X-ray microanalysis also in other cell types (e.g., sweat gland cells) after cAMP or $\mathrm{Ca}^{2+}$-induced $\mathrm{Cl}^{-}$efflux (Mörk and
Roomans, 1993; Mörk et al., 1995, 1996; Ring et al., 1995). The changes induced by exposing the cells to the hypoosmotic medium could be inhibited by chloride channel blockers and by addition of a calcium-chelating agent (indicating that efflux occurs via $\mathrm{Ca}^{2+}$-regulated $\mathrm{Cl}^{-}$-channels.)

\section{Subpopulations}

With X-ray microanalysis, many cells in a population can be analyzed, and individual data on each cell can be obtained. This makes it possible to detect inhomogeneities or subpopulation in the cell population investigated. von Euler and Roomans (1992) found that a culture of HT29 cells consisted of (at least) two subpopulations with respect to the K concentration. When the entire population was divided into "high K" and "low K" cells, using a frequency histogram of $\mathrm{K}$ concentrations, it was found that the two subpopulations differed not only in $\mathrm{K}$ but in most other elements as well. Mörk et al. (1995) found that only part of a primary culture of sweat gland cells reacted to cAMP stimulation with chloride efflux, whereas another subpopulation did not respond at all.

\section{Conclusions}

Because energy-dispersive X-ray microanalysis determines (changes in) the content of several elements in the cell simultaneously, the technique can detect patterns of change in several elements. These patterns can be used to identify the cellular process that results from exposure to a biomaterial or foreign substance. Because individual cells are analyzed, X-ray microanalysis can also give information on subpopulations of cells, both with regard to primary characteristics and with regard to their reaction to external stimuli.

Very little of these possibilities has so far been realized in the field of biomaterials. Increased use of this analytical technique will provide worthwhile information on cell-biomaterial interaction. 


\section{Acknowledgements}

Research reviewed in the paper was in part supported by grants from the Swedish Medical Research Council and the Swedish Heart Lung Foundation.

\section{References}

Abraham EH, Breslow JL, Epstein J, Chang-Sing P, Lechene C (1985) Preparation of individual human diploid fibroblasts and study of ion transport. Am. J. Physiol. 248: C154-C164.

Brodbeck WG, Shive MS, Colton E, Nakayama Y, Matsuda T, Anderson JM (2001) Influence of biomaterial surface chemistry on the apoptosis of adherent cells. J Biomed Mater Res 55: 661-668.

Cimpan MR, Cressey LI, Skaug N, Halstensen A, Lie SA, Gjertsen BT, Matre R (2000) Patterns of cell death induced by eluates from denture base acrylic resins in U937 human monoblastoid cells. Eur J Oral Sci 108: 59-69.

Dragomir A, Andersson C, Åslund M, Hjelte L, Roomans GM (2001) Assessment of chloride secretion in human nasal epithelial cells by X-ray microanalysis. J Microsc 203: 277-284.

Fabre T, Belloc F, Dupuy B, Schappacher M, Soum A, Bertrand-Barat J, Baquey C, Durandeau A (1999)Polymorphonuclear cell apoptosis in exudates generated by polymers. J Biomed Mater Res 44: 429-435.

Fernández-Segura E, Cañizares FJ, Cubero MA, Warley A, Campos A (1999) Changes in elemental content during apoptotic cell death studied by electron probe X-ray microanalysis. Exp Cell Res 253: 454-462.

Grängsjö A, Leijon-Kuligowski A, Törmä H, Roomans GM, Lindberg M (1996) Differences in the epidermal elemental content and expression of cytokines after application of two different irritants. Contact Derm 35: 355-360.

Grängsjö A, Pihl-Lundin I, Lindberg M, Roomans GM (2000a) X-ray microanalysis of cultured keratinocytes: methodological aspects and effects of the irritant sodium lauryl sulfate on elemental composition. J Microsc 199: 208-213.

Grängsjö A, Ybo A, Roomans GM, Lindberg, M (2000b) Irritant-induced keratinocyte proliferation evaluated with two different methods: immunohistochemistry and X-ray microanalysis. J Submicrosc Cytol Pathol 32: 11-16.

Grundin TG, Roomans GM, Forslind B, Lindberg M, Werner Y (1985) X-ray microanalysis of psoriatic skin. J Invest Dermatol 85: 378-380.

Hongpaisan J, Zhang AL, Mörk AC, Roomans GM (1996) Use of primary cell cultures and intact isolated glandular epithelia for X-ray microanalysis. J Microsc 184: 22 34.

Kampf C, Roomans GM (2001) Effect of hypochlorite on cultured respiratory epithelial cells. Free Radical Res 34: 499-511.

Kampf C, Relova AJ, Sandler S, Roomans GM (1999) Effects of TNF- $\alpha$, IFN- $\gamma$ and IL- $1 \beta$ on normal human bronchial epithelial (NHBE) cells. Eur Resp J, 14: 84-91.
Kuijpers GAJ, Roomans GM (1980) Post-mortem elemental redistribution in rat studied by X-ray microanalysis and electron microscopy. Histochemistry 69, 145-156.

Mörk A-C, Roomans GM (1993) X-ray microanalysis of cAMP-induced ion transport in NCL-SG3 sweat gland cells. Scanning Microsc 7: 1233-1240.

Mörk AC, Hongpaisan J, Roomans GM (1995) Ion transport in primary cultures from human sweat gland coils studied with X-ray microanalysis. Cell Biol Int 19: 151159.

Mörk AC, von Euler A, Roomans GM, Ring A (1996) cAMP-induced chloride transport in NCL-SG3 sweat gland cells. Acta Physiol Scand 157: 21-32.

Nkamgueu EM, Adnet JJ, Bernard J, Zierold K, Kilian L, Jallot E, Benhayoune H, Bonhomme P (2000) In vitro effects of zirconia and alumina particles on human blood monocyte-derived macrophages: X-ray microanalysis and flow cytometric studies. J Biomed Mater Res 52: 587-594.

Pariente JL, Kim BS, Atala A (2001) In vitro biocompatibility assessment of naturally derived and synthetic biomaterials using normal human urothelial cells. $\mathrm{J}$ Biomed Mater Res 55: 33-39.

Prabhu A, Shelburne CE, Gibbons DF (1998) Cellular proliferation and cytokine responses of murine macrophage cell line J774A.1 to polymethyl-methacrylate and cobaltchrome alloy particles. J Biomed Mater Res 42: 655-663

Ring A, Mörk A-C, Roomans GM (1995) Calcium-activated chloride fluxes in cultured NCL-SG3 sweat gland cells. Cell Biol Int 19: 265-278.

Roomans GM (1988a) Introduction to X-ray microanalysis in biology. J Electron Microsc Techn 9, 318

Roomans GM (1988b) Quantitative X-ray microanalysis of biological specimens. J Electron Microsc Techn 9, 19-44

Roomans GM (1990) X-ray microanalysis. In: PW Hawkes, U Valdrè (eds.) Biophysical Electron Microscopy (Academic Press, London), pp 347-412.

Roomans GM (2002) X-ray microanalysis of epithelial cells in culuture. In: Epithelial Cell Culture Protocols (Wise C, ed). Methods in Molecular Biology. Humana Press, Totowa, NJ, in press.

Salido M, Vilches J, Lopez A, Roomans GM (2001) $\mathrm{X}$-ray microanalysis of etoposide induced apoptosis in the PC-3 prostatic cancer cell line. Cell Biol Int 25: 499-508.

Salido M, Vilches J, Lopez A, Roomans GM (2002) Neuropeptides bombesin and calcitonin inhibit apoptosisrelated elemental changes in prostate cancer cell lines. Cancer, in press.

Sarkadi B, Parker JC (1991) Activation of ion transport pathways by changes in cell volume. Biochim Biophys Acta 1071: 407-427

Skepper JN, Karydis I, Garnett MR, Hegyi L, Hardwick SJ, Warley A, Mitchinson MJ, Cary N (1999). Changes in elemental concentrations are associated with early stages of apoptosis in human monocyte-macrophages exposed to oxidized low-density lipoprotein: an X-ray microanalytical study. J Pathol 188: 100-106.

Tobasnick ASG, Curtis A (2001) Chloride channels and the reactions of cells to topography. Eur Cell Mater, in press. 
von Euler A, Roomans GM (1992) Ion transport in colon cancer cell cultures studied by X-ray microanalysis. Cell Biol Int Rep 16: 293-306.

von Euler A, Pålsgård E, Vult von Steyern C, Roomans GM (1993) X-ray microanalysis of epithelial and secretory cells in culture. Scanning Microsc 7: 191-202.

Wallberg P, Lindberg M, Alsterborg E, Roomans GM, Wróblewski R (2000) Elemental changes in skin from patients with basal cell carcinoma. J Submicrosc Cytol Pathol 32: $169-173$.

Warley A (1997) X-ray Microanalysis for Biologists. In: Practical Methods in Electron Microscopy (Glauert AM, Series Editor), vol. 16. Portland Press, London

Warley A, Cracknell KP, Cammish HB, Twort CH, Ward JP, Hirst SJ (1994) Preparation of airway smooth muscle cells for study of element concentrations by X-ray microanalysis. J. Microsc. 175, 143-153.

Wróblewski R, Roomans GM, Kozlova E (2000) Effects of dorsal root transection on morphology and chemical composition of degenerating nerve fibers and reactive astrocytes in the dorsal funiculus. Exp Neurol 164: 236245.

Wróblewski R, Jalnäs M, Van Decker G, Björk J, Wroblewksi J, Roomans GM (2002) Effects of irradiation on intestinal cells in vivo and in vitro. Histol Histopathol, in press.

Zhang W, Roomans GM (1998) Volume induced chloride transport in HT29 cells studied by X-ray microanalysis. Microsc Res Techn 40: 72-78.

Zierold K, Hentschel H, Wehner F, Wessing A (1994) Electron probe X-ray microanalysis of epithelial cells: aspects of cryofixation. Scanning Microsc Suppl. 8: 117127.

\section{Discussion with Reviewers}

A. Warley: Although the author recommends that elemental ratios can be used to avoid full quantification could this not be misleading, for example an increase in $\mathrm{Na} / \mathrm{K}$ ratio is characteristic of both necrosis and apoptosis. Would the author like to comment?

Author: It is indeed correct that both in apoptosis and in necrosis the $\mathrm{Na} / \mathrm{K}$ ratio increases. In both cases, this is due to an increased concentration of $\mathrm{Na}$ and a decreased concentration of K. Fully quantitative analysis is not likely to be helpful here, since the same processes are responsible for the changes in $\mathrm{Na}$ and $\mathrm{K}$ both in necrosis and in apoptosis. What may be used to distinguish apoptosis from necrosis is is the fact that in apoptosis, $\mathrm{P}$ and $\mathrm{S}$ concentrations show marked changes. In particular for $\mathrm{P}$ we find a consistent significant increase. This is not the case in necrosis. Here, the concentration of $P$ remains the same as in the undamaged cell or decreases somewhat if structural damage is extensive. The concentration of $\mathrm{S}$ in necrosis generally remains unchanged. However, more work needs to be done to understand the elemental changes in apoptosis.

I. ap Gwynn: Would the author like to comment on those techniques that depend upon the incorporation of exotic elements into cells and tissues, to act as 'internal reference standards' for estimating the amounts of soluble intrinsic ions within cells.

Author: Any element in the cell, intrinsic or extrinsic, can be used as internal standard, i.e., if one knows the absolute concentration of one element in the cell, the absolute concentrations of other elements can be determined from their elemental ratios with regard to the internal standard element. Whether an intrinsic or extrinsic element is chosen as internal standard depends on the possibilities to determine its absolute concentration accurately by an alternative method. An example of such an alternative method would be the use of radioactive tracers. For accuracy the concentration of the extrinsic element should be quite high, so that determination of the peak intensity can be done without appreciable error. For this reason, the use of an incorporated extrinsic element would be limited to those elements that can be introduced into the cell in high concentrations without causing damage to the cell. The use of rubidium $(\mathrm{Rb})$ as an analogue for $\mathrm{K}$, or iodine (I) as an analogue for $\mathrm{Cl}$ would come to mind. 